\title{
A review of Ditua Waterhouse, 1879 with description of seven new species from New Guinea (Coleoptera: Lycidae)
}

\section{O6зор Ditua Waterhouse, 1879 с описанием семи новых видов из Новой Гвинеи (Coleoptera: Lycidae)}

\author{
Sergey V. Kazantsev \\ C.В. Казанцев
}

Insect Centre, Donetskaya 13-326, Moscow 109651, Russia.

Инсект-центр, ул. Донецкая 13-326, Москва 109651, Россия. E-mail: kazantss@mail.ru

KEY WORDS: Coleoptera, Lycidae, new species, Papuan region.

КЛЮЧЕВЫЕ СЛОВА: Coleoptera, Lycidae, новые виды, Папусская область.

ABSTRACT. Seven new species of net-winged beetles of the genus Ditua Waterhouse, 1879: D. balkei, $D$. elevaticostata, D. nigra, D. siniaevi, D. spinifera, D. telnovi and D. tuzovi spp.n. - are described from New Guinea and adjacent islands. Ditua dichroma (Boisduval, 1835), the type species of the genus, is illustrated. Ditua alternata Bourgeois, 1892 n.rev. is revalidated from synonymy with $D$. dichroma. A key to the species of Ditua is provided. Some autapomorphies of the genus are discussed.

РЕЗЮМЕ. Из Новой Гвинеи и прилегающих островов описывается семь новых видов жуков-краснокрылов рода Ditua Waterhouse, 1879: D. balkei, D. elevaticostata, $D$. nigra, $D$. siniaevi, $D$. spinifera, $D$. telnovi и $D$. tuzovi spp.n. Приводятся иллюстрации Ditua dichroma (Boisduval, 1835), типового вида рода Ditua. Ditua alternata Bourgeois, 1892 n.rev. восстанавливается из синонимии к D. dichroma. Приводится определительная таблица видов Ditua. Обсуждаются некоторые аутапоморфии рода.

\section{Introduction}

The tribe Metriorrhynchini, widely distributed in the Old World Palaetropics, is by far the most diverse and species-rich group of net-winged beetles in New Guinea [e.g., Kleine, 1933; Bocák, 2002], accounting for more than half of the described taxa of the region's lycid fauna.

An opportunity to study the vast Lycidae collections of the Institut Royal de Sciences naturelles de Belgique, Bruxelles, the Erfurt Naturkundemuseum and the Entomological Society of Latvia has already led to publication of several papers on Metriorrhynchini of New Guinea [Kazantsev, 2007, 2010, 2015a-b, 2016]. Further studies make it possible to contribute to the knowledge of the genus Ditua Waterhouse, 1879. Ditua, like many other metriorrhynchine genera in New Guinea, is endemic to the region. Four species were described in this genus, but only two have retained validity [Kleine, 1933]. In the present paper Ditua alternata Bourgeois, 1892, n.rev. is revalidated from synonymy with $D$. dichroma (Boisduval, 1835), D. dichroma, the type species of the genus, is illustrated, and seven new Ditua species are described.

\section{Material and Methods}

Most of the studied lycid specimens were collected by light traps. Other collecting methods included beating, Malaise traps, ultraviolet, white and mercury-vapor light.

The studied specimens were pinned or glued on cardboard plates. For a detailed examination they were relaxed in water; then the detached ultimate abdominal segments were treated for several hours in $10 \% \mathrm{KOH}$ at room temperature, then, with the extracted genitalia, placed in microvials with glycerin; or, glued back on cardboard plates.

MSP-1 zoom stereoscopic dissecting microscope with $\mathrm{x} 8-\mathrm{x} 80$ magnification range was used. Photographs were taken with Canon EOS 6D camera and Canon MPE $65 \mathrm{~mm}$ lens.

The following acronyms are used in the paper: DTC - private collection of Dr. D. Telnov, Riga; ICM - Insect Center, Moscow; IRSN — Institut Royal de Sciences naturelles de Belgique, Bruxelles; NME Naturkundemuseum, Erfurt.

\section{Taxonomy}

Ditua Waterhouse, 1879

Ditua Waterhouse, 1879: 33

Type species: Ditua deplanata Waterhouse, 1878 (= Calopteron dichroma Boisduval, 1835).

REMARKS. Four species were described in this genus [Waterhouse, 1878, 1879; Bourgeois, 1892], one of which was found synonymous with an earlier taxon classified as a 
Calopteron Guerin-Meneville, 1830 [Bourgeois, 1892]. In a paper on net-winged beetles of New Guinea Kleine [1926], having studied Bourgeois's types, placed two of the three species described by Bourgeois in synonymy with $D$. dichro$m a$, the type species of the genus. However, Bourgeois's description clearly indicates that at least one of these two taxa, D. alternata Bourgeois, 1892, is very different and apparently deserves to be separated from $D$. dichroma. Oddly, the name Ditua flaviceps Bourgeois, 1892, the only Bourgeois's taxon that retained validity after Kleine's examination, was misspelt by Kleine both in the New Guinean paper and in the World Lycidae Catalogue as Ditua flavipes [Kleine, 1926, 1933].

DISTRIBUTION. New Guinea and adjacent islands.

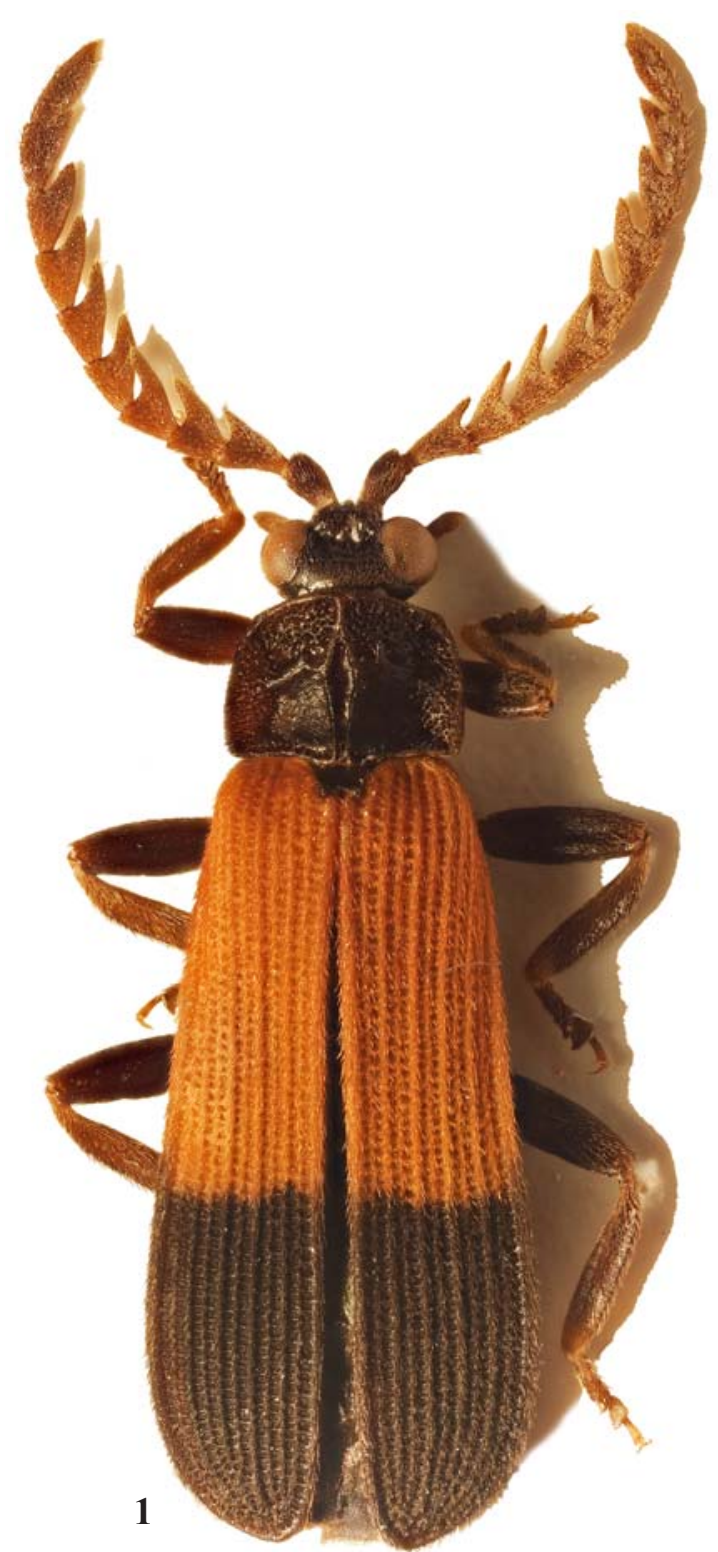

Ditua dichroma (Boisduval, 1835)

Figs 1-4.

Calopteron dichroma Boisduval, 1835: 123;

= Ditua deplanata Waterhouse, 1878: 100, 109;

= Ditua nigricornis Bourgeois, 1892: 513.

MATERIAL: $55 \sigma^{7} \sigma^{7}$ and 16 우, Papua New Guinea, Madang prov., Baiteta, light, O. Missa leg., dates: 10.IV.1993, 21.IV.1993, 22.IV.1993, 16.IV.1994, 1995, IV.1996, 8.IV.1996, 10.IV.1996, 13.IV. 1996, 15.IV.1996, 23.IV.1996, 24.IV.1996, 29.IV.1996, 14.V.1996, 16.V.1996, 19.V.1996, 20.V.1996, 23.V.1996, 27.V.1996, 30.V.1996, 3.VI.1996, 4.VI.1996, 5.VI.1996, 10.VI.1996, 12.VI.1996, 14.VI. 1996, 18.VI.1996, 20.VI.1996, 25.VI.1996, 27.VI.1996, 1.VII.1996, 4.VII.1996, 10.VII.1996, 18.VII.1996, 25.VII.1996; E Indonesia, Irian Jaya, 170 km S Nabire, Epomani, 1150 m, 6.I.1996, A. Weigel leg.; E Indonesia, Irian Jaya, Wapoga River, 64 km E Asori, Kwadewa Camp, $2^{\circ} 49^{\prime} \mathrm{S}, 136^{\circ} 28^{\prime} \mathrm{E}, 10 . \mathrm{I} .1999$, A. Weigel leg.; E Indonesia,
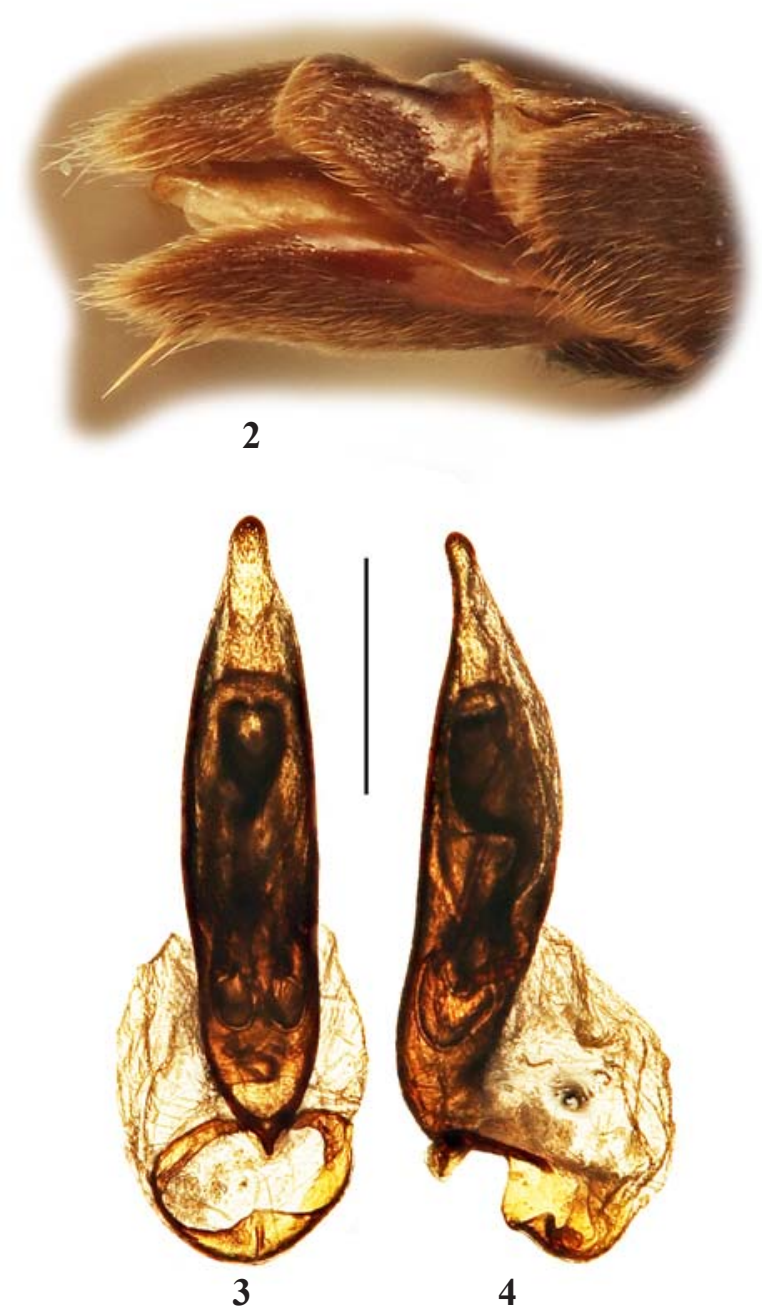

4

Figs 1-4. General view and details of Ditua dichroma, $0^{7}: 1$ - general view; 2 - ultimate abdominal segments; 3 -4 - aedeagus; 1,3 dorsally; 2, 4 - laterally. Scale: $0.5 \mathrm{~mm}$.

Рис. 1-4. Общий вид и детали строения Ditua dichroma, o: 1 - общий вид; $3-4-$ эдеагус; 1,3 - сверху; $2,4-$ сбоку. Масштабная линейка: 0.5 мм. 
Irian Jaya, Nabire area, road Nabire-Ilaga, $3^{\circ} 30^{\prime} 936^{\prime \prime} \mathrm{S}, 135^{\circ} 41^{\prime} 945^{\prime \prime} \mathrm{E}$ 250 m, LEK, X.1997, M. Balke leg.; E Indonesia, Irian Jaya, Jayapura, Lake Santani, Sudufer, 100 m, VI.1998, M. Balke leg. (ICM, IRCN and NME).

REMARKS. The illustrated original description of Ditua deplanata Waterhouse, 1878, although brief, seems to be sufficient to attribute relevant Ditua specimens to the taxon, and to contest the attribution of the specimen illustrated by Bocák [2002] to D. deplanata, as agreeing with it neither in the structure, nor in the shape of the pronotum. For instance, the description (supported by the accompanying illustration) indicates that the «thorax [is] nearly semicircular, bisinuate at the base; the mesial lanceolate areola is narrow, and from the middle of each side of it there is an indication of a raised line which does not quite reach the side of the thorax» [Waterhouse, 1878]. In Bocák's illustration [Bocák, 2002, Fig. 80] actually all of these characters are quite in the opposite condition.

The female Ditua dichroma differs from the male in having smaller eyes and more narrow, just serrate antennae.

DISTRIBUTION. The species is widely distributed in New Guinea.

\section{Ditua alternata Bourgeois, 1892 n.rev.}

Ditua alternata Bourgeois, 1892: 515.

REMARKS. The description of Ditua alternata Bourgeois, 1892 indicates that flabellae of male median antennomeres in this species are several times longer than their stems [Bourgeois, 1892], which is quite different from $D$. dichro$m a$, to which it was considered to be synonymous, where flabellae of male median antennomeres are hardly longer than their stems. This means that the two taxa are apparently different and Bourgeois' taxon needs to be revalidated as Ditua alternata Bourgeois, 1892 n.rev.

DISTRIBUTION. New Guinea (Fly River; Dorey) [Bourgeois, 1892].

Ditua flaviceps Bourgeois, 1892

Ditua flaviceps Bourgeois, 1892: 515;

= Ditua flavipes: 162 (Kleine, 1926: 515) (lapsus kalami).

REMARKS. Ditua flaviceps Bourgeois, 1892 is readily distinguishable from congeners by the reddish testaceous head and front and middle legs, with almost straight anterior margin of the pronotum [Bourgeois, 1892]. In this respect it is possible that this species does not actually belong in Ditua, as all its known members, including the type species and species described herein as new, have differently shaped pronotum. 1892].

DISTRIBUTION. New Guinea (Hatam) [Bourgeois,

\section{Ditua balkei Kazantsev, sp.n.}

Figs 5-7.

MATERIAL: Holotype, $0^{7}$, E Indonesia, Irian Jaya, Nabire area, road Nabire-Ilaga, 330'936"S, 135 41'945"E, 250 m, LEK, X.1997, M. Balke leg. (NME); paratype, $\sigma^{7}$, same label (ICM).

DESCRIPTION. Male. Orange testaceous; antennae, except antennomere 2, elytral distal two thirds, abdomen, femoris distally, tibiae, except proximally, and tarsi dark brown to black.

Vertex shining, finely punctate, with shallow transverse impression behind antennal prominence. Eyes small, interocular distance ca. 1.6 times greater than eye diameter. Labrum small, transverse, straight anteriorly. Palps slender, ultimate palpomeres elongate, nearly parallel-sided, flattened and glabrous distally. Antennal sockets separated by narrow lamina.
Antennae flattened, feebly flabellate, attaining to elytral two thirds; flabellae noticeably shorter than relative stems; antennomere 3 ca. 6 times longer than antennomere 2 and subequal in length to antennomere 4; antennomeres 3-11 with short sub-erect pubescence (Fig. 5).

Pronotum transverse, ca. 1.4 times as wide as long, with explanate sides, bisinuate basally and rounded anteriorly, with small acute posterior and rounded anterior angles; median cell narrow, reaching anterior margin; lateral carinae curved, disappearing near lateral margins; anterior cells not diverging anteriorly, formed by weak antero-lateral carinae. Mesothoracic spiracle with long narrow bent backwards hood. Scutellum transverse, slightly narrowing distally, emarginate at apex (Fig. 5).

Elytra narrow, long, ca. 3.5 times longer than wide at humeri, slightly widening distally, with slender, equally developed primary costae; all interstices with double rows of elongate or rounded cells; bottom of cells glabrous; pubescence relatively long and semi-erect (Fig. 5). Femoris and tibiae straight, relatively broad; tarsomeres 3-4 moderately widened, tarsomere 1 without plantar pad.

Ultimate sternite with spine. Aedeagus with narrow, cylinder-like median lobe; inner sac with scissors-like proximal and hooked distal structures; membrane of phallobase relatively short, ca. 0.3 length of median lobe (Figs 6-7).

Female. Unknown.

Length: 6.0-6.4 mm. Width (humerally): 1.5-1.6 mm.

ETYMOLOGY. The new species is named after collector of the type series Dr. M. Balke.

DIAGNOSIS. Ditua balkei sp.n. can be separated from D. elevaticostata sp.n., also with orange pronotum and narrow, reaching anterior margin median pronotal cell, by the long elytral pubescence and relatively narrow, cylinder-like median lobe of the aedeagus (Figs 5-7).

DISTRIBUTION. Known only from Nabire area, Irian Jaya.

\section{Ditua nigra Kazantsev, sp.n.}

Figs 8-10.

MATERIAL: Holotype, $\sigma^{\top}$, Papua New Guinea, $10 \mathrm{~km} \mathrm{~N}$ Madang, 2 km NNW Riwo, 9-11.II.1989, M. \& R. Holyñski leg. (ICM).

DESCRIPTION. Male. Dark brown to black; antennomere 2, trochanters and bases of femoris light brown.

Vertex shining, with deep transverse impression behind antennal prominence. Eyes relatively large, interocular distance subequal in length to eye diameter. Rostrum short. Labrum small, transverse. Palps slender, ultimate palpomeres elongate, narrowed and glabrous distally. Antennal sockets separated by narrow lamina. Antennae flabellate, attaining to elytral middle; flabellae of median antennomeres ca. 1.2 times longer than relative stems; antennomere 3 ca. 5 times longer than antennomere 2 and ca. 1.1 times longer than antennomere 4; antennomeres 3-11 with short sub-erect pubescence (Fig. 8).

Pronotum transverse, ca. 1.2 times as wide as long, widest near anterior angles, bisinuate basally and triangularly produced anteriorly, with small acute posterior and conspicuous blunt anterior angles; median cell narrow, almost reaching anterior margin; lateral carinae curved, inconspicuous near lateral margin; anterior cells slightly diverging anteriorly, formed by inconspicuous antero-lateral carinae. Mesothoracic spiracle with narrow bent backwards hood. Scutellum transverse, parallel-sided, conspicuously emarginate at apex (Fig. 8).

Elytra long, ca. 3.3 times longer than wide at humeri, parallel-sided, with slender, equally developed primary cos- 
tae; all interstices with double rows of rounded cells; bottom of cells glabrous; pubescence short and semi-erect (Fig. 8). Tibiae and femoris straight, relatively broad; tarsomeres 3-4 widened, tarsomeres 1-2 with minute apical plantar pad.

Ultimate sternite with spine. Aedeagus with straight, narrow and distally split median lobe; inner sac with scissorslike structure; membrane of phallobase attaining to 0.4 length of median lobe (Figs 9-10).

Female. Unknown.
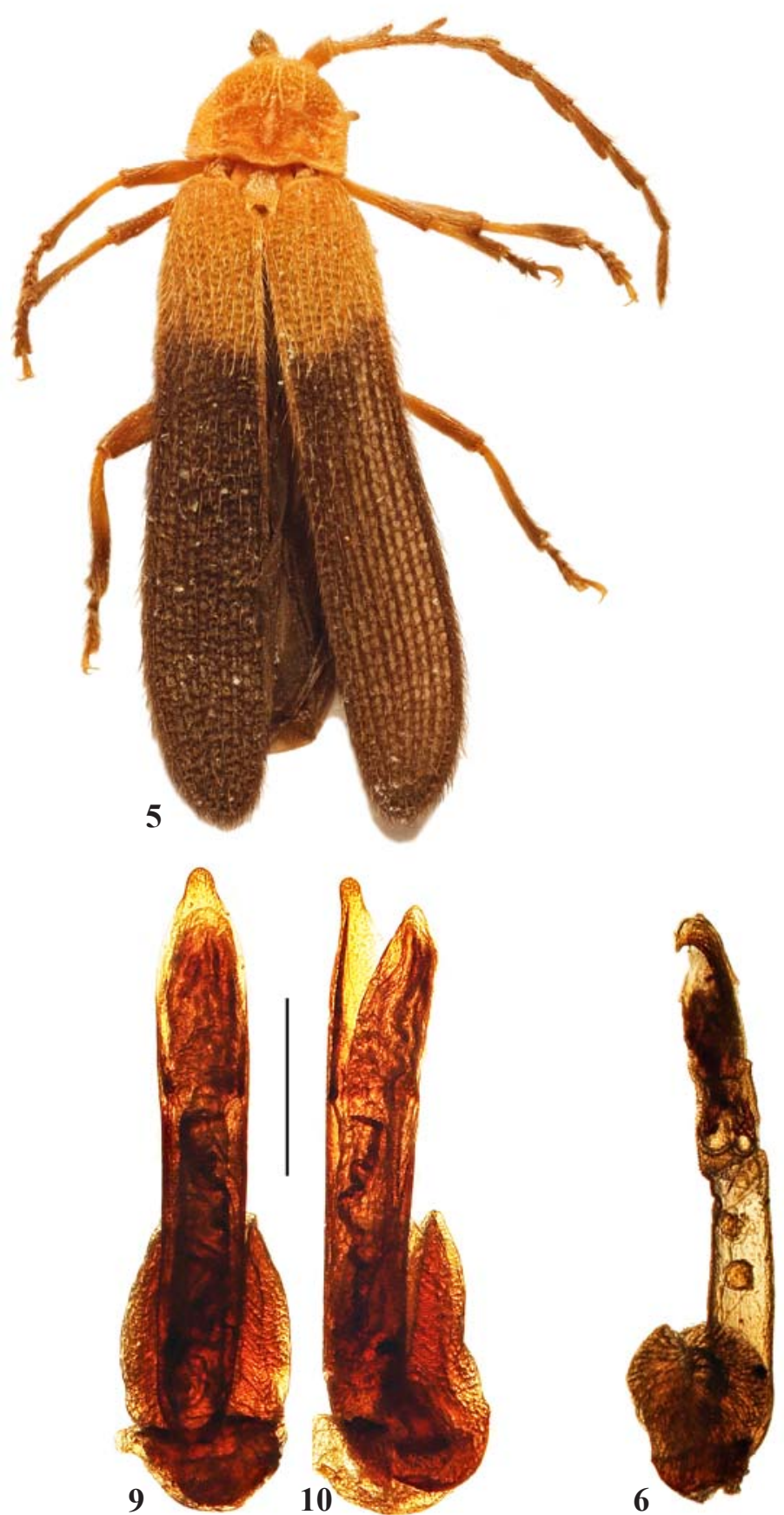

Length: $6.8 \mathrm{~mm}$. Width (humerally): $1.6 \mathrm{~mm}$

ETYMOLOGY. The name of the new species is derived from the Latin for "black", alluding to its coloration.

DIAGNOSIS. Ditua nigra sp.n. can be separated from all congeners by the uniformly dark brown to black upperside, noticeably widened anteriorly pronotum and straight, narrow and distally split median lobe of the aedeagus (Figs 8-10). Guinea.

DISTRIBUTION. Known only from Madang, Papua New

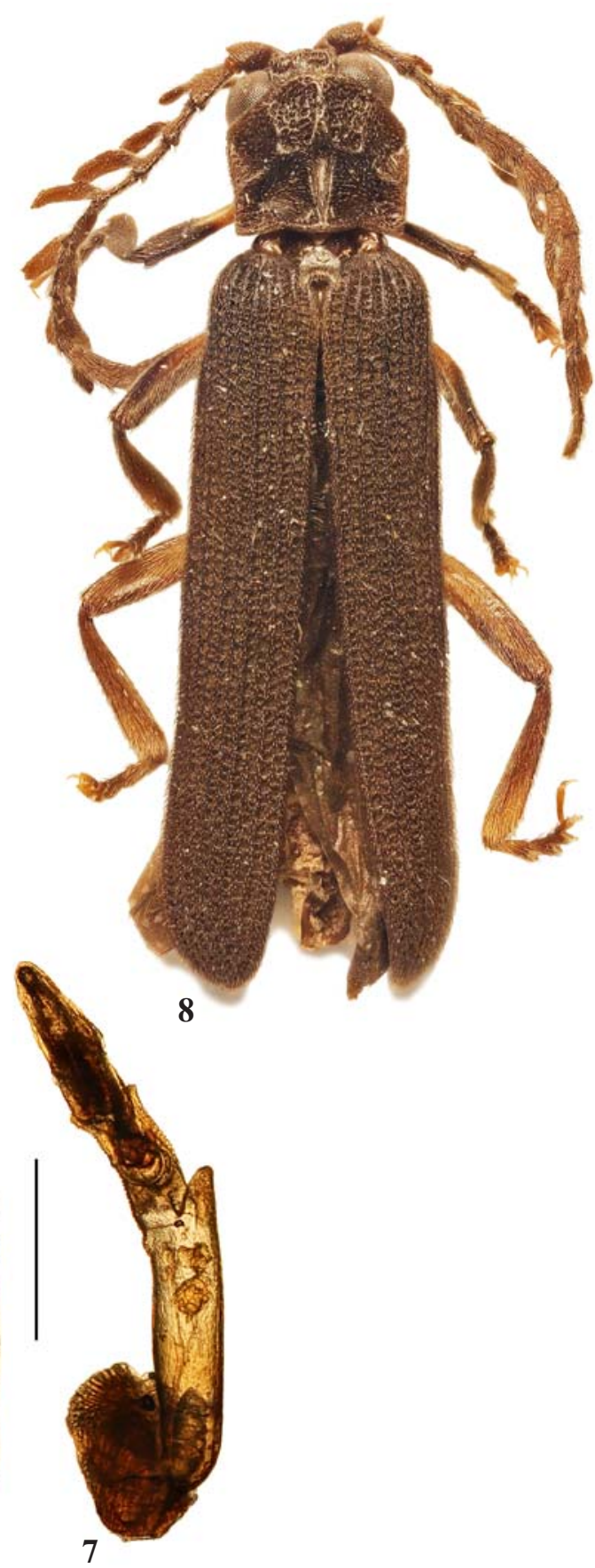

Figs 5-10. General view and details of Ditua, holotype $\sigma^{7} \sigma^{7}: 5-7-D$, balkei sp.n.; $8-10-D$. nigra sp.n.; 5 , $8-$ general view; $6-$ 7, 9-10 - aedeagus (6-7 with inner sac extracted); 5-6, 8-9 - dorsally; 7, 10 - laterally. Scales: $0.5 \mathrm{~mm}$.

Рис. 5-10. Общий вид и детали строения Ditua, голотипы, от э’: 5-7 - D. balkei sp.n.; 8-10 - D. nigra sp.n.; 5, 8 - общий вид; 6-7, 9-10 - эдеагус (6-7 с извлечённым внутренним мешком); 5-6, 8-9 - сверху; 7, 10 - сбоку. Масштабные линейки: 0.5 мм. 


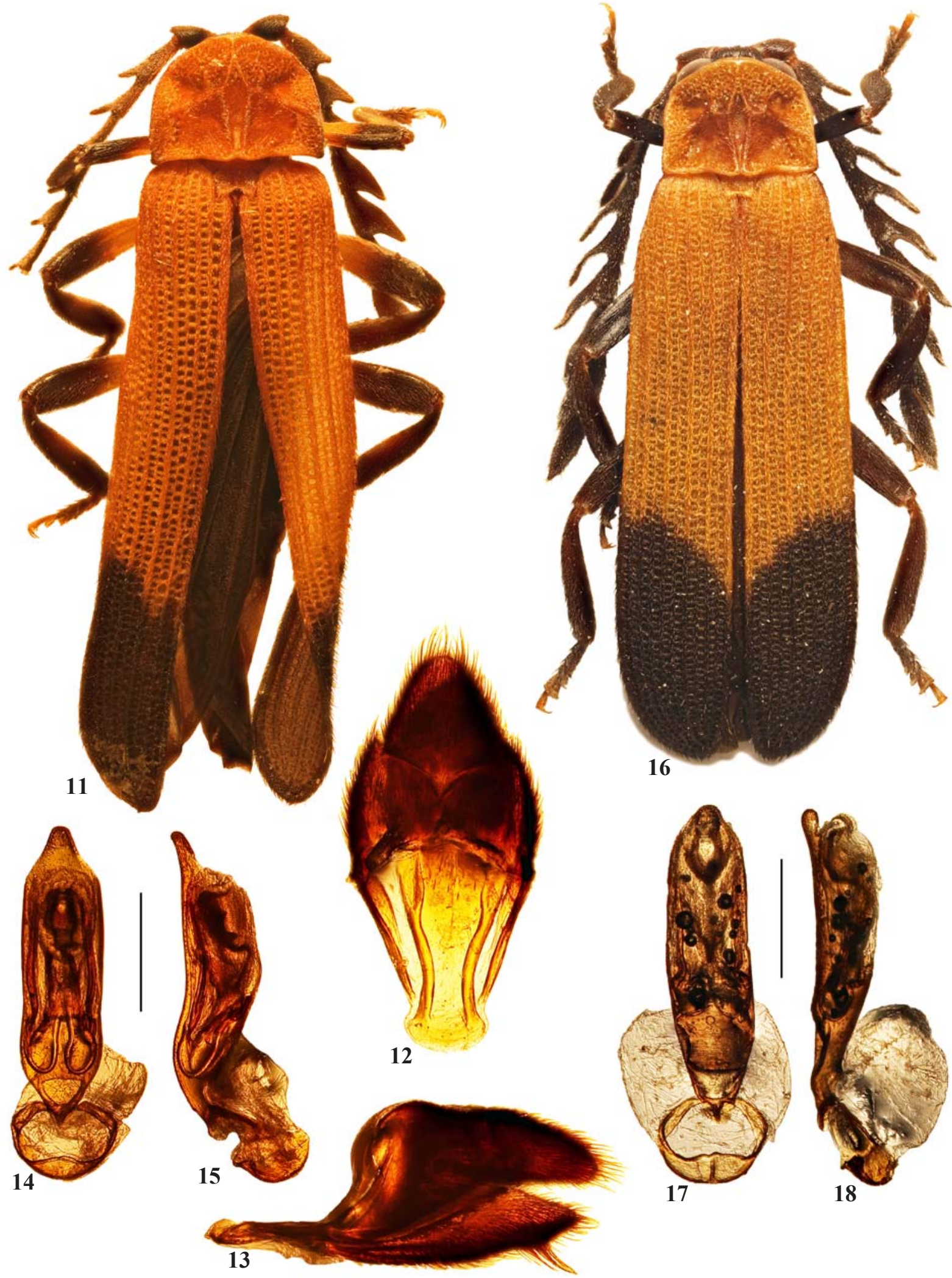

Figs 11-18. General view and details of Ditua, holotype $0^{7} 0^{7}$ : 11-15 - D. elevaticostata sp.n.; 16-18 - D. siniaevi sp.n.; 11,16 - general view; 12-13 - ultimate abdominal segments; 14-15, 17-18 - aedeagus; 11-12, 14, 16-17 - dorsally; 13, 15, 18 - laterally. Scales: $0.5 \mathrm{~mm}$. Рис. 11-18. Общий вид и детали строения Ditua, голотипы, оำ: 11-15-D. elevaticostata sp.n.; 16-18 - D. siniaevi sp.n.; 11, 16 - общий вид; 12-13 - вершинные сегменты брюшка; 14-15, 17-18 - эдеагус; 11-12, 14, 16-17 - сверху; 13, 15,18 - сбоку. Масштабные линейки: 0.5 мм. 


\section{Ditua elevaticostata Kazantsev, sp.n. Figs 11-15.}

MATERIAL: Holotype, $\sigma^{7}$, Indonesia, Maluku Utara (North Moluccas) Prov., Halmahera Tengah (Central), Wada Selatan distr., SW Loleo vill., $0^{\circ} 13^{\prime} 58.16^{\prime \prime} \mathrm{N}, 127^{\circ} 54^{\prime} 27.18^{\prime \prime} \mathrm{E}$, roadside, between plantations, beaten from dry leaves, 12.IX.2007, D. Telnov \& K. Greke leg. (NME); paratypes,, , N Moluccas, Halmahera Is., Talagaranu Mt., $15 \mathrm{~km}$ SE Baru, $600 \mathrm{~m}$, primary forest, 22-31.I.1996, V. Siniaev \& E. Afonin leg. (ICM); 9 , Indonesia, Maluku Utara (North Moluccas) Prov., Halmahera Tengah (Central), Wada Selatan distr., $15-18 \mathrm{~km}$ SW Tilope, S Loleo vill., Oham, $0^{\circ} 14^{\prime} 46.74^{\prime \prime} \mathrm{N}, 127^{\circ} 52^{\prime}$ $38.1{ }^{\prime \prime} \mathrm{E}, 150 \mathrm{~m}$, primary lowland forest, beaten, 13-14.IX.2007, D Telnov \& K. Greke leg. (DTC); ㅇ, Indonesia, Maluku Utara (North Moluccas) Prov., Halmahera Tengah (Central), Wada Selatan distr. $18 \mathrm{~km}$ SW Tilope, S Loleo vill., Oham, $0^{\circ} 14^{\prime} 46.74^{\prime \prime} \mathrm{N}, 127^{\circ} 52^{\prime} 38$. $19^{\prime \prime} \mathrm{E}, 120 \mathrm{~m}$, edge of primary lowland forest, UV light, 16.IX.2007, D. Telnov \& K. Greke leg. (ICM).

DESCRIPTION. Male. Orange testaceous. Antennae, except antennomere 2, ultimate palpomeres, femoris, except in proximal halves, tibiae, tarsi, except ultimate tarsomeres, and abdomen black.

Vertex shining, finely punctate, with shallow roundish impression behind antennal prominence. Eyes relatively small, interocular distance ca. 1.5 times greater than eye diameter. Labrum small, transverse, slightly convex medially. Palps slender, ultimate palpomeres elongate, oblique and glabrous distally. Antennal sockets separated by narrow lamina. Antennae strongly serrate, attaining to elytral three fifths; antennomere 3 ca. 6 times longer than antennomere 2 and ca. 1.1 times longer than antennomere 4 ; antennomeres 3-11 with short sub-erect pubescence (Fig. 11).

Pronotum transverse, ca. 1.4 times as wide as long, almost semicircular, feebly bisinuate basally, with small acute posterior and no anterior angles; median cell moderately narrow, nearly reaching anterior margin; lateral carinae slightly curved, obsolete near lateral margins; anterior cells diverging anteriorly, formed by vague antero-lateral carinae. Mesothoracic spiracle with elongate bent backwards hood. Scutellum transverse, slightly narrowing distally, triangularly emarginate at apex (Fig. 11).

Elytra flat, long, ca. 3.4 times longer than wide at humeri, parallel-sided, with robust, equally developed primary costae; all interstices with double rows of small subquadrate cells; bottom of cells dark, glabrous; pubescence short and semi-erect (Fig. 11). Tibiae and femoris straight, femoris moderately broad; tarsomeres 2-4 widened, tarsomeres 1-4 with plantar pads.

Ultimate sternite with spine formed by several long bristles; penultimate tergite deeply incised, divided by median suture; ultimate sternite proximally dilated and rounded (Figs 12-13). Aedeagus with relatively robust medially parallelsided and curved in lateral view median lobe; inner sac with scissors-like sclerotised structure and parallel lateral bars; membrane of phallobase short, attaining to only 0,2 length of median lobe (Figs 14-15).

Female. Similar to male, but eyes somewhat smaller and antennae somewhat shorter.

Length: $9.0-10.6 \mathrm{~mm}$. Width (humerally): $2.2-2.8 \mathrm{~mm}$.

ETYMOLOGY. The name of the new species is derived from the Latin for "with elevated costae", alluding to its relatively stout primary elytral costae.

DIAGNOSIS. Ditua elevaticostata sp.n. is to be placed near $D$. balkei sp.n., easily separable by the conspicuously shorter elytral pubescence, shorter black distal elytral area and robust, curved (in lateral view) median lobe of the aedeagus (Figs 11, 14-15).
DISTRIBUTION. Known only from Halmahera Island, North Moluccas.

\section{Ditua siniaevi Kazantsev, sp.n. \\ Figs 16-18.}

MATERIAL: Holotype, $\sigma^{\top}$, N Moluccas, Bacan Is., Sibela Mt., $14 \mathrm{~km}$ SE Labuna, $400 \mathrm{~m}$, primary forest, 2-13.II.1996, V. Siniaev \& E. Afonin leg. (ICM)

DESCRIPTION. Male. Dark brown to black; antennomere 2, pronotum, scutellum, thorax, elytra, except at distal third, coxae and trochanters orange testaceous.

Vertex shining, finely punctate, with shallow roundish impression behind antennal prominence. Eyes relatively large, interocular distance ca. 1.1 times shorter than eye diameter. Labrum small, transverse, slightly convex medially. Palps slender, ultimate palpomeres elongate, narrowed and glabrous distally. Antennal sockets separated by narrow lamina. Antennae flabellate, attaining to elytral three fifths; flabellae of median antennomeres ca. 1.2 times longer than relative stems; antennomere $3 \mathrm{ca} .7$ times longer than antennomere 2 and ca. 1.2 times longer than antennomere 4; antennomeres 3-11 with short sub-erect pubescence (Fig. 16).

Pronotum transverse, ca. 1.3 times as wide as long, with almost parallel sides, feebly bisinuate basally and rounded anteriorly, with small acute posterior and noticeable blunt anterior angles; median cell narrow, almost reaching anterior margin; lateral carinae curved, obsolete near lateral margins; anterior cells diverging anteriorly, formed by vague anterolateral carinae. Mesothoracic spiracle with triangular bent backwards hood. Scutellum transverse, slightly narrowing distally, emarginate at apex (Fig. 16).

Elytra flat, long, ca. 3.2 times longer than wide at humeri, parallel-sided, with slender, equally developed primary costae; all interstices with double rows of small subquadrate cells; bottom of cells glabrous; pubescence short and semi-erect (Fig. 16). Tibiae and femoris straight, relatively broad; tarsomeres 3-4 widened, tarsomeres 1-2 with apical plantar pad.

Ultimate sternite with spine. Aedeagus with robust oval median lobe; inner sac with scissors-like sclerotised structure; membrane of phallobase attaining to 0,4 length of median lobe (Figs 17-18).

Female. Unknown.

Length: 9.4-11.2 mm. Width (humerally): 2.2-2.6 mm.

ETYMOLOGY. The new species is named after one of the collectors of the type series Mr. V. Siniaev (Moscow).

DIAGNOSIS. Ditua siniaevi sp.n. is to be placed near $D$. elevaticostata sp.n., separable by the noticeably longer flabellae of male antennomeres and more bent in lateral view and more constricted apically median lobe of the aedeagus (Figs 16-18).

DISTRIBUTION. Known only from Bacan Island, North Moluccas.

\section{Ditua spinifera Kazantsev, sp.n.} Figs 19-23.

MATERIAL: Holotype, O7, Papua New Guinea, Madang prov., Baiteta, light, 24.VI.1996, O. Missa leg. (IRCN); paratypes, $5 \mathrm{O}^{2} \mathrm{O}^{7}$ and O, same label, dates: 31.III.1993, 30.IV.1996, 13.V.1996, 24.VI.1996, 3.VII.1996, 18.VII.1996 (ICM and IRCN); paratype, + , Indonesia, Irian Jaya, $50 \mathrm{~km} \mathrm{~S} \mathrm{Nabire,} \mathrm{Ilaga} \mathrm{road,} \mathrm{Pusppensaat} \mathrm{Station,} 3^{\circ} 29.5^{\prime} \mathrm{S}$, 1354ㄱ.8'E, 300 m, LEK, X.1997, M. Balke leg. (NME).

DESCRIPTION. Male. Dark brown to black; elytra, except at distal third, thorax, coxae and bases of femoris orange testaceous.

Vertex shining, finely punctate, with shallow transverse impression behind antennal prominence. Eyes relatively small, 
interocular distance ca. 1.5 times greater than eye diameter. Labrum moderately large, transverse, convex and emarginate medially. Palps small, ultimate maxillary palpomeres slightly longer than wide, nearly parallel-sided. Antennal sockets separated by narrow triangular lamina. Antennae flabellate, attaining to elytral three fifths; flabellae of median antennomeres subequal in length to relative stems; antennomere $3 \mathrm{ca}$. 5 times longer than antennomere 2 and ca. 1.5 times longer than antennomere 4; antennomeres 3-11 with short sub-erect pubescence (Fig. 19).

Pronotum transverse, ca. 1.4 times as wide as long, with noticeably concave sides, bisinuate basally and convex anteriorly, with prominent acute posterior and conspicuous blunt anterior angles; median cell broad, attaining to ca. 0.75 length of pronotum; lateral carinae curved, near lateral margins prominent; anterior cells broad, not diverging anteriorly, formed by straight antero-lateral carinae. Mesothoracic spiracle with elongate narrow bent backwards hood. Scutellum transverse, slightly narrowing distally, conspicuously emarginate at apex (Fig. 19).

Elytra long, ca. 3.1 times longer than wide at humeri, parallel-sided, with slender, equally developed primary costae; all interstices with double rows of small mostly transverse cells; bottom of cells glabrous; pubescence short and semierect (Fig. 19). Tibiae and femoris straight, broad; tarsomeres 3-4 widened, tarsomeres 1-2 with apical plantar pad.

Ultimate sternite with prominent spine (Fig. 20). Aedeagus with parallel-sided in dorsal view and slightly widened distally in lateral view median lobe; inner sac with scissors- like sclerotised structure; membrane of phallobase short, attaining only to 0.3 length of median lobe (Figs 21-22).

Female. Similar to male, but eyes smaller and antennae non-flabellate, just serrate.

Length: $6.7-10.8 \mathrm{~mm}$. Width (humerally): $1.9-2.8 \mathrm{~mm}$.

ETYMOLOGY. The name of the new species is derived from the Latin for "bearing a spine", alluding to the structure of its terminal sternite.

VARIATION. In one of the paratypes only the proximal quarter of the elytra is orange testaceous, the rest being dark brown to black (Fig. 18).

DIAGNOSIS. Ditua spinifera sp.n. can be separated from all congeners by the broad medial pronotal cell and raised and prominent near lateral margins lateral pronotal carinae, as well as by the parallel-sided and slightly widened distally in lateral view median lobe of the aedeagus (Figs 19, 21-23).

DISTRIBUTION. Registered in Madang, Papua New Guinea, and Irian Jaya.

\section{Ditua telnovi Kazantsev, sp.n.} Figs 24-26.

MATERIAL: Holotype, $0^{\top}$, E Indonesia, West Papua, Fak-Fak peninsula, 5-7 km N Fak-Fak, $02^{\circ} 53^{\prime} 26^{\prime \prime} \mathrm{S}, 132^{\circ} 18^{\prime} 22^{\prime \prime} \mathrm{E}, 300-400$ $\mathrm{m}$, primeval lowland rainforest on limestone, 23.IX.2010, D. Telnov leg. (NME).

DESCRIPTION. Male. Dark brown to black; antennomere 2, palps, pronotum, scutellum, thorax, elytra, except at distal half, coxae, trochanters and femurs and tibiae proximally orange testaceous.
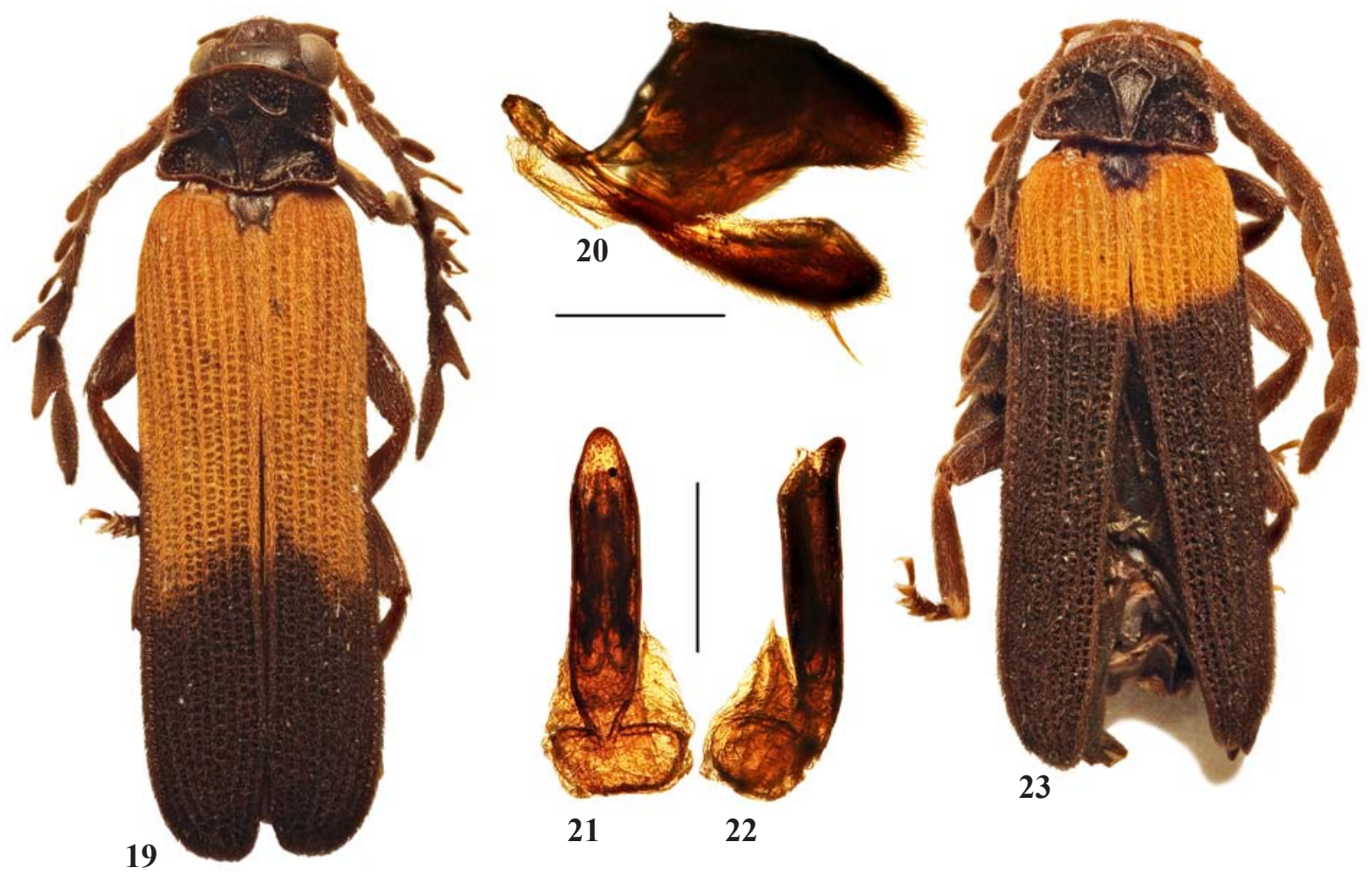

Figs 19-23. General view and details of Ditua spinifera sp.n., $0^{7} 0^{7}: 19,23$ - general view; 20 - ultimate abdominal segments; 21-22 aedeagus; $19-22$ - holotype; 23 - paratype; 19, 21, 23 - dorsally; 20, 22 - laterally. Scales: $0.5 \mathrm{~mm}$.

Рис. 19-23. Общий вид и детали строения Ditua spinifera sp.n., о $\sigma^{7}$ : 19, 23 - общий вид; 20 - вершинные сегменты брюшка; 21-22 — эдеагус; 19-22 - голотип; 23 - паратип; 19, 21, 23 - сверху; 20, 22 - сбоку. Масштабные линейки: 0.5 мм. 
Vertex shining, finely punctate, with shallow transverse impression behind antennal prominence. Eyes relatively small, interocular distance ca. 1.5 times greater than eye diameter. Labrum small, transverse. Palps slender, ultimate palpomeres elongate, narrowed and glabrous distally. Antennal sockets separated by narrow lamina. Antennae flattened, broad, serrate, attaining to elytral two thirds; antennomere 3 ca. 7 times longer than antennomere 2 and ca. 1.2 times longer than antennomere 4; antennomeres 3-11 with short sub-erect pubescence (Fig. 24).

Pronotum transverse, ca. 1.3 times as wide as long, with almost parallel sides, bisinuate basally and prominently rounded anteriorly, with small acute posterior and rounded anterior angles; median cell relatively broad, attaining to ca. 0.7

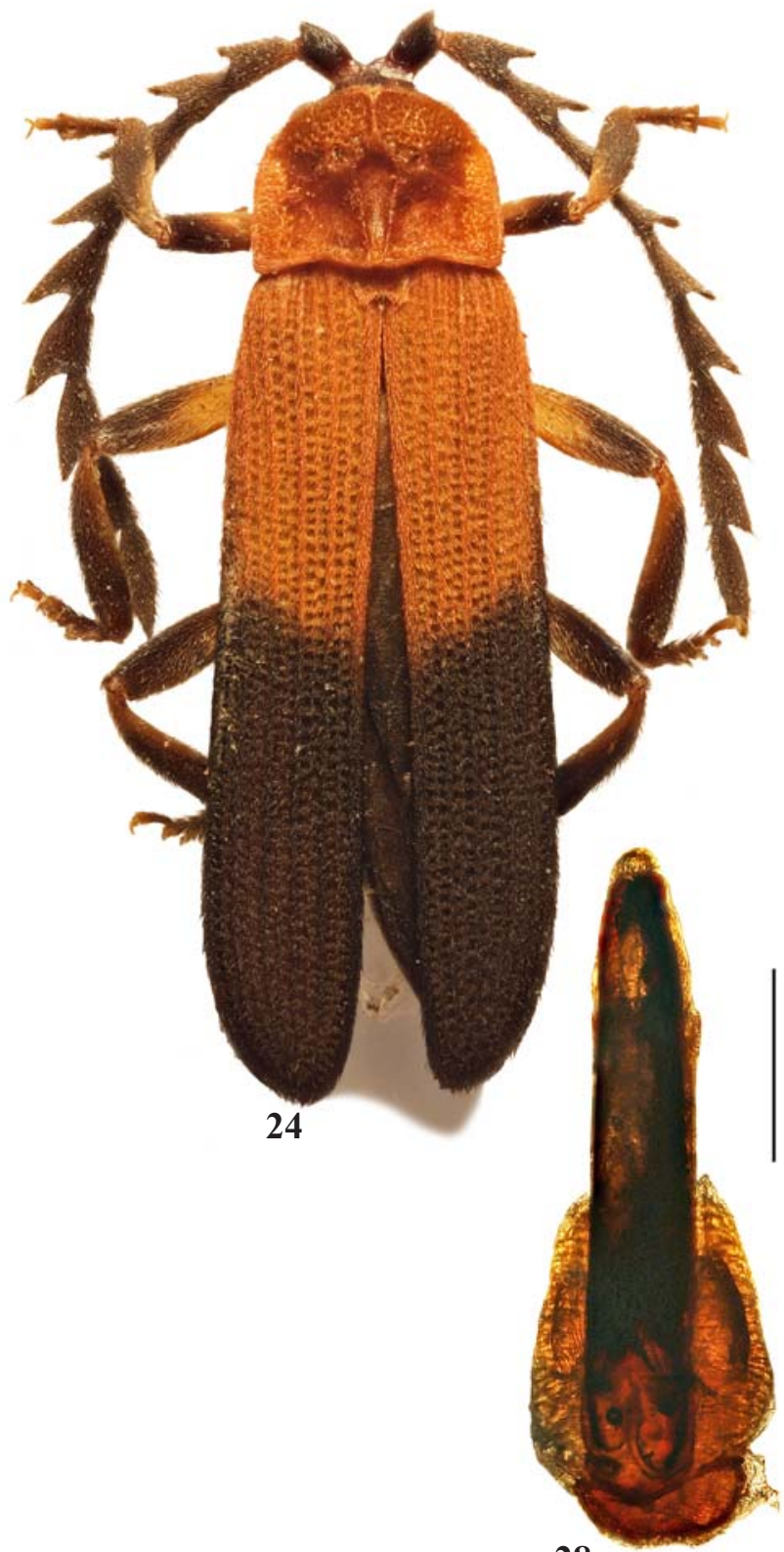

28 length of pronotum; lateral carinae obsolete near lateral margins; anterior cells obscure. Mesothoracic spiracle with elongate narrow bent backwards hood. Scutellum transverse, slightly narrowing distally, emarginate at apex (Fig. 24).

Elytra long, ca. 3 times longer than wide at humeri, parallel-sided, with slender, equally developed primary costae; all interstices with double rows of small subquadrate cells; bottom of cells glabrous; pubescence short and semi-erect (Fig. 24). Tibiae and femoris straight, relatively broad; tarsomeres 3-4 widened, tarsomeres 1-2 with apical plantar pad.

Ultimate sternite with spine. Aedeagus with narrowed both proximally and distally median lobe; inner sac with scissors-like sclerotised structure; membrane of phallobase short, attaining to ca. 0.3 length of median lobe (Figs 25-26).

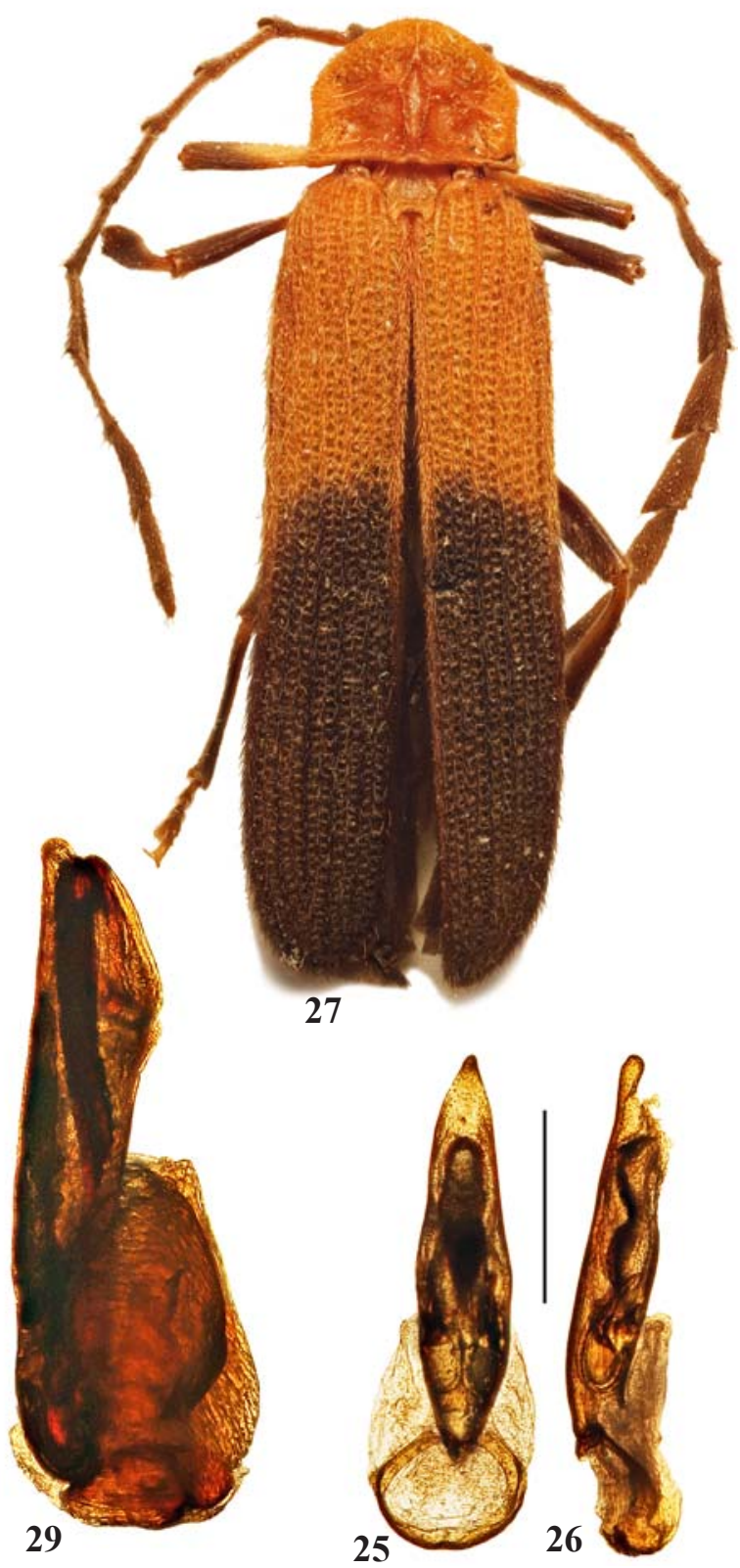

Figs 24-29. General view and details of Ditua, holotype $0^{7} 0^{7}$ : 24-26 - D. telnovi sp.n.; 27-29 - D. tuzovi sp.n.; $24,27-$ general view; 25-26, 28-29 - aedeagus; 24-25, 27-28 - dorsally; 26, 29 - laterally. Scales: $0.5 \mathrm{~mm}$.

Рис. 24-29. Общий вид и детали строения Ditua, голотипы, о $0^{7}$ : 24-26 - D. telnovi sp.n.; 27-29 — D. tuzovi sp.n.; 24, 27 - общий вид; 25-26, 28-29 - эдеагус; 24-25, 27-28 - сверху; 26, 29 - сбоку. Масштабные линейки: 0.5 мм. 
Female. Unknown.

Length: $7.9 \mathrm{~mm}$. Width (humerally): $2.0 \mathrm{~mm}$.

ETYMOLOGY. The new species is named after collector of the type specimen Dr. Dm. Telnov (Riga).

DIAGNOSIS. Ditua telnovi sp.n. is separable from the similar $D$. tuzovi sp.n. by the broader pronotal median cell and relatively small, narrowed both proximally and distally median lobe of the aedeagus (Figs 24-26).

DISTRIBUTION. Known only from West Papua.

\section{Ditua tuzovi Kazantsev, sp.n.} Figs 27-29.

MATERIAL: Holotype, $0^{\top}$, Indonesia, Irian Jaya, Nabire area, 750 m, 28.V.1995, V. Tuzov leg. (ICM).

Description. Male. Dark brown to black; antennomere 2, palps, pronotum, scutellum, thorax, elytra, except at distal half, coxae, trochanters and femurs proximally orange testaceous.

Vertex shining, finely punctate, with shallow transverse impression behind antennal prominence. Eyes relatively large, interocular distance subequal in length to eye diameter. Labrum small, transverse. Palps slender, ultimate palpomeres elongate, narrowed distally. Antennal sockets separated by narrow lamina. Antennae flattened, relatively narrow, serrate, attaining to elytral four fifths; antennomere $3 \mathrm{ca} .8$ times longer than antennomere 2 and subequal in length to antennomere 4; antennomeres 3-11 with short sub-erect pubescence (Fig. 27).

Pronotum transverse, ca. 1.4 times as wide as long, with almost parallel sides, slightly bisinuate basally and strongly rounded anteriorly, with small acute posterior and rounded anterior angles; median cell relatively narrow, attaining to ca. 0.8 length of pronotum; lateral carinae obsolete near lateral margins; anterior cells obscure. Mesothoracic spiracle with long narrow bent backwards hood. Scutellum transverse, parallel-sided, emarginate at apex (Fig. 27).

Elytra narrow, long, ca. 3.3 times longer than wide at humeri, parallel-sided, with slender, equally developed primary costae; all interstices with double rows of small roundish cells; bottom of cells glabrous; pubescence short and semi-erect (Fig. 27). Tibiae and femoris straight, relatively broad; tarsomeres 3-4 widened, tarsomeres 1-2 with apical plantar pad.

Ultimate sternite with spine. Aedeagus with relatively large, parallel-sided median lobe; inner sac with scissors-like sclerotised structure; membrane of phallobase relatively long, attaining to ca. 0.5 length of median lobe (Figs 28-29).

Female. Unknown.

Length: $8.0 \mathrm{~mm}$. Width (humerally): $2.0 \mathrm{~mm}$.

ETYMOLOGY. The new species is named after collector of the type specimen Dr. V. Tuzov (Moscow).

DIAGNOSIS. Ditua tuzovi sp.n. is distinguishable from D. telnovi sp.n., by the narrow median pronotal cell and relatively large, parallel-sided median lobe of the aedeagus (Figs 27-29) Jaya.

DISTRIBUTION. Known only from Nabire area, Irian

Key to the species of Ditua Waterhouse, 1879

1. Flabellae of median male antennomeres several times longer than antennal stems

D. alternata Bourgeois n.rev.

- Male antennae serrate or flabellae of median antennomeres at most slightly longer than relevant antennal stems ... 2

2. Anterior pronotal margin almost straight. Front and middle legs testaceous D. flaviceps Bourgeois
- Anterior pronotal margin conspicuously convex. Front and middle legs mostly black ................................. 3

3. Median pronotal cell narrow, almost reaching anterior margin ............................................................... 4

- Median pronotal cell relatively broad, anteriorly connected with margin via carina ........................................... 8

4. Upperside uniformly dark brown to black. Pronotum noticeably widened anteriorly. Aedeagus with straight, narrow and distally split median lobe (Figs 8-10)

D. nigra sp.n.

- Upperside differently coloured 5

5. Pronotum uniformly black. Elytra reddish testaceous with black distal third. Aedeagus with widened in the middle median lobe (Figs 1-4) ......... D. dichroma (Boisduval)

— Pronotum reddish testaceous ......................................... 6

6. Flabellae of male antennae noticeably shorter than relative stems

- Flabellae of median male antennomeres noticeably than antennal stems. Aedeagus with narrowed proximally and slightly concave in lateral view median lobe (Figs 1618) D. siniaevi sp.n.

7. Elytra slightly widened distally, with black distal two thirds, in long pubescence. Aedeagus with parallel-sided cylinder-like median lobe (Figs 5-7) ..... D. balkei sp.n.

- Elytra parallel-sided, with black distal third, in very short pubescence. Aedeagus with broader, parallel-sided in dorsal view and noticeably bent proximally and concave medially in lateral view median lobe (Figs 11-15) ....... D. elevaticostata sp.n.

8. Lateral pronotal carinae raised and prominent near lateral margins, medial cell broad. Aedeagus with more narrow, parallel-sided and slightly widened distally in lateral view median lobe (Figs 19-23) ................. D. spinifera sp.n.

- Lateral pronotal carinae conspicuously weakened near lateral margins, median cell noticeably more narrow (Figs 24, 27)

9. Median pronotal cell broader. Aedeagus with relatively small, narrowed both proximally and distally median lobe (Figs 24-26) D. telnovi sp.n.

- Median pronotal cell narrow. Aedeagus with relatively large, parallel-sided median lobe (Figs 27-29)

D. tuzovi sp.n.

\section{Discussion}

Ditua dichroma, the type species of the genus Ditua, is characterized by the combination of rounded anteriorly pronotum, with narrow median cell almost reaching anterior margin and conspicuously weakened near lateral margins lateral pronotal carinae, presence of a spine on ultimate male sternite and scissors-like inner sac structure of the aedeagus (Figs 1-4). None of these characters are unique, each of them being not infrequent among other metriorrhynchines.

All Ditua species, including the new ones described above, share the last two mentioned characters with D. dichroma. The structure of their pronota, however, was found to vary in terms of width and length of the median cell and development of the transverse carinae near lateral margins. The median cell tends to range from narrow, as in D. dichroma (Fig. 1) to broad, as in 
D. spinifera sp.n. (Figs 19, 23) and from attaining the anterior margin (as in D. balkei sp.n., Fig. 5) to constituting only 0.7 length of pronotum (as in D. telnovi sp.n., Fig. 24). The transverse carinae may be completely obsolete near lateral margins (as in $D$. telnovi sp.n., Fig. 24) or fully developed (as in D. spinifera sp.n., Figs 19, 23).

Nevertheless, Ditua may well prove to represent a monophyletic taxon, but a more substantiated decision on its status should be made after the actual phylogeny of this lineage of net-winged beetles is re-examined on the basis of a comprehensive morphological analysis. Apparently, this should be preceded by extensive alphataxonomic studies, as only a fraction of the actual number of metriorrhynchine taxa from New Guinea seem to have been described.

ACKNOWLEDGEMENTS. It is my pleasant duty to express gratitude to Dr. P. Grootaert (Institut Royal de Sciences naturelles de Belgique, Bruxelles), Dr. M. Hartmann (Naturkundemuseum Erfurt) and Dr. D. Telnov (Entomological Society of Latvia, Riga), through whose courtesy I was able to study the Lycidae collections under their care. My sincere thanks are also due to Dr. R. Holyński (Milanowek, Poland), Dr. A. Kopetz (Kerspleben, Germany), Mr. V. Siniaev and Dr. V. Tuzov (Moscow) for providing interesting additional material collected during their entomological expeditions to New Guinea and adjacent islands.

\section{References}

Bocák L. 2002. Generic revision and phylogenetic analysis of the Metriorrhynchinae (Coleoptera: Lycidae) // European Journal of Entomology. Vol.99. P.315-351.

Bourgeois J. 1892. Lycides nouveaux ou peu connus de Musée Civique de Gênes. Deuxième mémoire. Deuxième partie. Soustribu des Lycini (genuini). A. Lycides de la Nouvelle-Guinée et des îles avoisinantes // Annali del Museo Civico di Storia Naturale di Genova. Vol.32. P.495-516.

Kazantsev S.V. 2007. Marena gen.n., new Metriorrhynchini genus from New Guinea (Coleoptera: Lycidae) // Russian Entomological Journal. Vol.16. No.3. P.297-300.

Kazantsev S.V. 2010. New taxa of Papuan net-winged beetles (Lycidae, Coleoptera) // Latvijas Entomologs. Vol.48. P.92-100.

Kazantsev S.V. 2015a. New Xylobanus and related taxa of netwinged beetles from New Guinea (Coleoptera: Lycidae) // Russian Entomological Journal. Vol.24. No.2. P.107-118.

Kazantsev S.V. 2015b. New species of Metriorrhynchus Gemminger et Harold, 1869 and Porrostoma Laporte, 1838 from New Guinea (Coleoptera: Lycidae) // Russian Entomological Journal. Vol.24. No.3. P.211-233.

Kazantsev S.V. 2016. New Procautires species from New Guinea (Coleoptera: Lycidae) // Russian Entomological Journal. Vol.25. No.1. P. 35-47.

Kleine R. 1926. Coleoptera. Lycidae // Nova Guinea. Résultats des Expéditions scientifiques à la Nouvelle Guinée. Vol.15. Leide, E.J. Brill. P.91-195.

Kleine R. 1933. Pars 123: Lycidae. Coleopterorum Catalogus auspiciis et auxilio W. Junk editus a Schenkling. W. Junk, Berlin. 145 pp.

Waterhouse C.O. 1878. On the different forms occurring in the Coleopterous family Lycidae, with descriptions of new genera and species // Transactions of Entomological Society of London. Vol.1. P. 95-118.

Waterhouse C.O. 1879. Illustrations of Typical Specimens in the Collection of the British Museum. Part 1 - Lycidae. London, Taylor and Francis. 93 pp. 